\title{
Assessment of mosquito larvae (Diptera: Culicidae) productivity in urban cemeteries in Wroclaw (SW Poland)
}

\author{
Katarzyna Rydzanicz $^{1}$ (D) $\cdot$ Aleksandra Czułowska $^{1}$ (D) $\cdot$ Dagmara Dyczko $^{1}$ (D) $\cdot$ Dorota Kiewra $^{1}$ (D)
}

Received: 8 July 2020 / Accepted: 22 December 2020 / Published online: 3 February 2021

(C) The Author(s) 2021

\begin{abstract}
In many European countries, cemeteries are found to be suitable habitats for the proliferation of native and invasive mosquito species. The study aimed to assess for the first time in Poland the suitability of urban cemeteries for mosquito larvae development in water supply wells. From May to September 2019 in three urban cemeteries in Wroclaw (SW Poland), a total of 757 inspection of water supply wells were carried out. The mosquito larvae development, expressed as the general container index (GCI), differed between the examined areas and months of the study. The highest GCI value was calculated for Grabiszyński and Bujwida cemeteries (72.0\% and 59.3\% respectively). Larvae of three native mosquito species were identified in all inspected breeding places during the survey: Culex pipiens s.l. Linnaeus (95\%), Cx. torrentium Martini (4\%), Anopheles maculipennis s.l. Meigen (less than 1\%). No larvae of invasive Aedes mosquito species were found. In the inspected water supply wells larval productivity peaked in June, when the average temperature reached $22.7^{\circ} \mathrm{C}$. Due to the likelihood of the establishment and adaptation of invasive aedine mosquito species in Poland, constant analysis of the larvae composition in cemeteries should be continued.
\end{abstract}

Keywords Culicidae $\cdot$ Larvae surveillance $\cdot$ Poland $\cdot$ Urban cemeteries

\section{Introduction}

For a better estimation of the threat of mosquito-borne diseases in European regions, studies on the occurrence of mosquito breeding sites in urban environments have been conducted (Krüger et al. 2014, Lebl et al. 2015). In addition to native mosquito fauna, surveillance of the introduction and establishment of Aedes invasive species has been carried out in cities, including cemeteries, of many European countries

Katarzyna Rydzanicz

katarzyna.rydzanicz@uwr.edu.pl

Aleksandra Czułowska

aleksandra.czulowska@uwr.edu.pl

Dagmara Dyczko

dagmara.dyczko@uwr.edu.pl

Dorota Kiewra

dorota.kiewra@uwr.edu.pl

1 Institute of Genetics and Microbiology, Department of Microbial Ecology and Environmental Protection, University of Wrocław, Przybyszewskiego str. 63/77, 51-148 Wrocław, Poland such as in Austria (Seidel et al. 2016, Zielke et al. 2016), Croatia (Klobučar et al. 2018), the United Kingdom (Dallimore et al. 2017), France (Krebs et al. 2014), Germany (Pluskota et al. 2008, Becker et al. 2011, Schneider 2011, Werner et al. 2012, Werner and Kampen 2013, Zielke et al. 2015, Pfitzner et al. 2018), Italy (Montarsi et al. 2013, Montarsi et al. 2015), Slovenia (Kalan et al. 2017) and Switzerland (Schaffner et al. 2009). From the identified species, five of them namely Aedes albopictus (Skuse, 1895), Ae. aegypti (Linnaeus, 1762), Ae. japonicus (Theobald, 1901), Ae. koreicus (Edwards, 1917) and Ae. atropalpus (Coquillett, 1902) are container-breeding and anthropophilic (ECDC 2012). Their occurrence and spread constitute a serious threat to public health in Europe as most of them are vectors of numerous pathogens, in particular arboviruses such as chikungunya virus (CHIKV) and dengue virus (DENV) (Medlock et al. 2012, 2015; Kampen et al. 2016). For this reason, as well as from an anthropocentric point of view, the knowledge about suitable breeding sites for mosquito vector species such as cemeteries in urban areas is of special interest.

In almost every human settlement around the world, from megalopolises with millions of inhabitants to small villages, cemeteries are an obligatory and specified area (Vezzani et al. 
2005, Vezzani 2007). Burial sites are visited by large numbers of people but also provide a great deal of vegetation cover and a lower edification level, resulting in higher landscape connectivity. This facilitates insect breeding and dispersal. In cemeteries, there is typically also a large number of artificial containers, such as flasks, bottles, flower vases or water wells, which enable the development of preimaginal stages of mosquitoes, thus creating a diverse nuisance level of mosquito females (Vezzani 2007, Kampen et al. 2016). Cemeteries offer also appropriate habitats for adult mosquitoes such as bushes and trees that provide shade and shelter. Most cemeteries are public property making them easily accessible; this generates permanent food sources for adult mosquitoes including flowering plants left by visitors, the blood of human visitors and on-site workers, and the blood of birds and small mammals (Koban et al. 2019).

In contrast to many European and global studies, the surveys on qualitative and quantitative composition of mosquito fauna in Polish cemeteries have not been carried out and published to date. Therefore, the main objective of the present study was to estimate the breeding opportunities of Culicidae within water supply wells in the cemeteries of Wrocław (SW Poland), taking into account climate conditions, while investigating the seasonal dynamics and species composition of the immature stages of mosquitoes in cemeteries, including the presence verification of Aedes invasive species.

\section{Materials and methods}

\section{Study site}

The study was conducted in the southwestern Poland, in the city of Wroclaw, which is the capital of Lower Silesia. Wroclaw and its surrounding areas form the Wroclaw Plain, which is, in turn, geomorphologically part of the Silesian Plain (Kondracki 2000). It has an elevation of 120-150 m above the sea level and is divided into two unequal parts by the wide Odra River valley. This area experiences a climate characterized by mild and short winters, early springs, and long, warm summers, which is unique for Poland (Cichocki 2006). This is a result of geographical location in Lower Silesia, within the transitory belt between the oceanic and continental influences, as well as the combined influence of the arctic-tropical and sea-continental air masses. The climate of Wrockaw's region is especially marked by a rather high average annual temperature, ranging in 2019 from $0.2{ }^{\circ} \mathrm{C}$ in January to $22.7^{\circ} \mathrm{C}$ in June (average $11.5^{\circ} \mathrm{C}$ ). Average annual precipitation is at the level of $453 \mathrm{~mm}$, there is a 225 -days vegetation period, and winters are endure only a short period of snow cover (https:// danepubliczne.imgw.pl).
The study was conducted from May to September 2019 in three cemeteries namely: Grabiszyński (GR), Bujwida (BU) and Jerzmanowo (JE). Two of them (GR and BU) are located in the city center and are surrounded by houses and tall buildings (Fig. 1). The third cemetery (JE: Jerzmanowo) is located on the outskirts of the city, close (approx. $2 \mathrm{~km}$ ) to International Airport, where there are some family homes but less tall buildings. The GR and JE cemeteries are public (run by municipal authorities) and BU belongs to the group of parish cemeteries. All the inspected cemetery areas were characterized by diverse species composition and vegetation density; however, the greatest environmental heterogeneity and landscape values occurred in GR (Gizowska and Szopińska 2013, Przewrocka and Ziemiańska 2013a,b). The current borders of the GR cemetery are one of the three parts of cemetery complex, which was founded in 1881; it has a total area of approx. 20 ha and is an object with very high natural and landscape values (Burak and Okólska 2007; http://zck.wroc.pl/ cmentarze-komunalne/oddzial-grabiszyn). BU cemetery is a small cemetery with an area of 4.3 ha, which was founded in 1866 (Burak and Okólska 2007). JE cemetery is the smallest in the study, at 2.7 ha, and was established in 1998; the relative newness of the site means vegetation in this area is less dense than in the other studied areas (https://www.wroclaw.pl/cmentarz-naJerzmanowie).

\section{Sampling of immature mosquitoes}

Mosquito larvae were sampled from May to September 2019 within water supply wells (Fig. 2).

Water supply wells were identified in each inspected cemetery using maps obtained from the Cemeteries Board. All existing and potential breeding habitats in the study areas were recorded using a GPS receiver and transferred to the computer database. The construction of all water supply wells was similar; however, the number of wells differed across the three cemeteries: 81 water supply wells were confirmed in GR cemetery compared to only 9 in JE and 6 in BU, respectively. Additionally, the water levels in the water supply wells varied throughout the study period. All potential mosquito breeding sites were checked in cemeteries once per month in May and twice per month from June to September.

One dip was taken with a standard dipper (volume $350 \mathrm{ml}$ ) in each water supply well per visit. The number of larval stages L1L2, L3-L4, and pupae were counted and recorded. All immature mosquitoes (larvae and pupae) were transferred to the laboratory where, to enable species identification, the larvae of L1-L3 were reared to L4 stage and pupae were reared to adult.

The four instar larvae (L4) were killed by thermal shock with hot water $\left(60^{\circ} \mathrm{C}\right)$, collected with a fine pipette, and then put in a vial filled with an $80 \%$ solution of ethanol. The fourth instar larvae of Culex sp. were morphologically determined 


\section{Legend:}

+ Airport

Airport area

Cemetery area
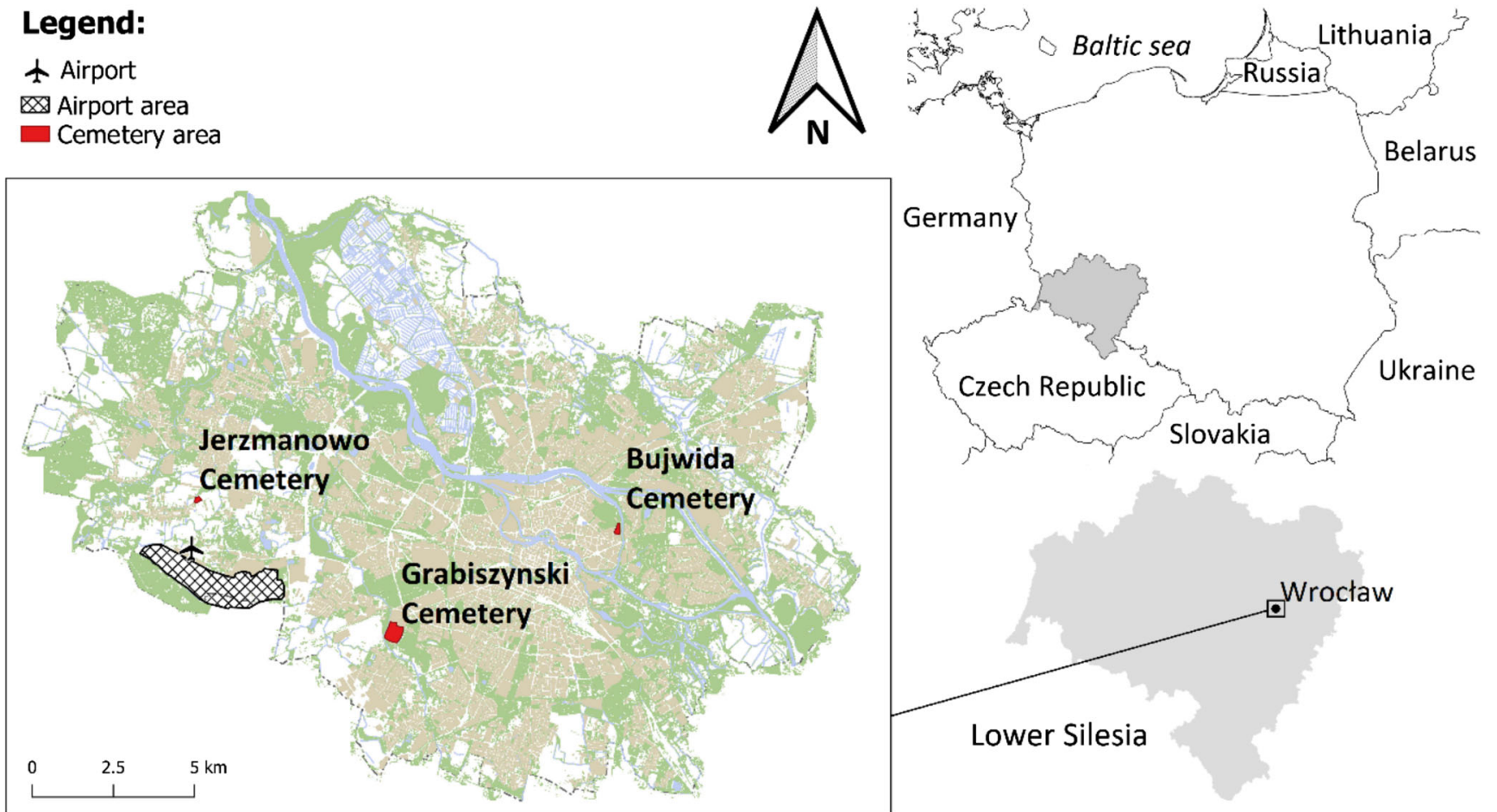

Fig. 1 Location of study sites in the Wrocław area

according to Becker et al. (2010). Using a stereoscopic microscope the number of setae 1 at the abdominal segments III to $\mathrm{V}$ was assessed. The larvae of Culex pipiens s.l. possess regularly two or two and three setae at each place, whereas Culex torrentium is described to have each four setae at each place (Becker et al. 2010). The larvae belonging to Anopheles maculipennis complex were assessed on the basis of morphological features located on the larval head including the

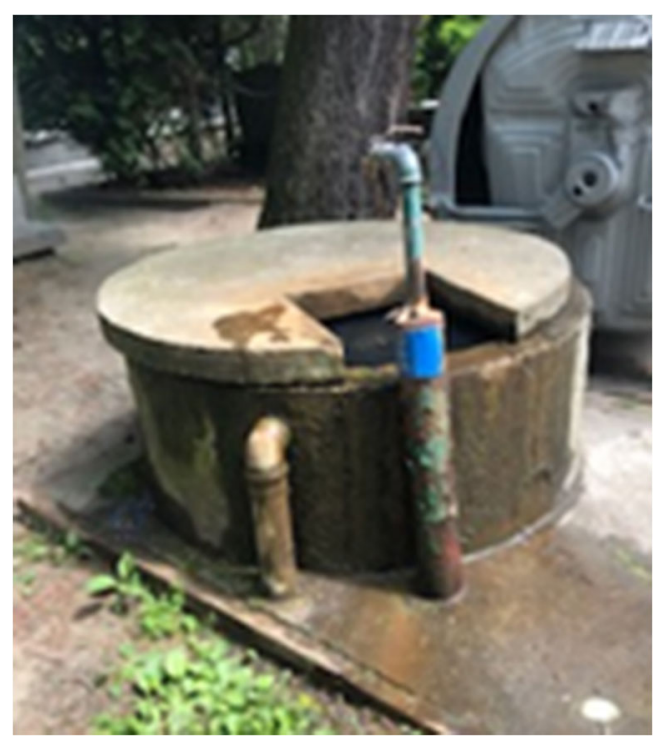

Fig. 2 An example of a water supply well widely present in selected Wroclaw cemeteries structure of the antennal seta, inner and outer clypeal setae as well as frontal setae (Becker et al. 2010).

\section{Data analysis}

Mosquito larvae productivity in each cemetery was expressed as the general container index (GCI) according the formula: $\mathrm{GCI}=$ number of breeding sites containing larvae/ total number of breeding sites x 100 (Petrić et al. 2014).

In the study period, meteorological data regarding average monthly precipitation, sunlight duration per day, and air temperature in Wrocław area were obtained from the Institute of Meteorology and Water Management - National Research Institute (Rocznik Meteorologiczny 2019, https:// danepubliczne.imgw.pl).

\section{Results}

Overall, 492 (65\%) of 757 inspected water supply wells tested positive for mosquito immature stages; 448 in GR, 32 in BU and 12 in JE (Table 1). In total, larvae of three mosquito species were identified: Culex pipiens s.l. L. (95\%), Cx. torrentium Martini (4\%) and Anopheles maculipennis s.1. Meigen (less than 1\%). No larvae of invasive Aedes mosquito were found.

Mosquito larvae productivity varied between inspected cemeteries (Table 1). During the period the value of GCI 
Table 1 Breeding sites measurements and container indices at all cemeteries of Wrocław

\begin{tabular}{lllll}
\hline Indices & \multicolumn{2}{l}{ Cemetery } & & \\
\cline { 2 - 5 } & Bujwida (BU) & Grabiszyński (GR) & Jerzmanowo (JE) \\
\hline Number of water supply wells & 6 & 81 & 9 & \\
No. of breeding sites inspected & 54 & 622 & 81 & \\
No. of breeding sites with larvae & 32 & 448 & 12 & \\
General container index, \% (GCI) & 59.3 & 72.0 & 14.8 & \\
\hline
\end{tabular}

was the highest for GR and BU cemeteries ( $\mathrm{GCI}=72.0 \%$ and $59.3 \%$ respectively). In turn water supply wells in JE cemetery offered the least suitable breeding containers for mosquito larvae $(\mathrm{GCI}=14.8 \%)$.

The sample size in a single $350 \mathrm{ml}$ dip varied between 0 and 110 individuals. In the GR mosquito larvae developed throughout the whole study period, while in the BU and JE were only found from June to September (Table 2). The value of GCI varied from 0 in May (BU and JE) to $91.67 \%$ in June and July (BU).

The most intense mosquito larvae development occurred in June and July when GCI varied from $84.25 \%$ in the GR cemetery to $91.67 \%$ in the BU cemetery. In August, a decrease in the development rate and number of mosquito larvae was observed in all cemeteries. This decline was also recorded in September.

Mosquito larvae productivity in the water supply wells inspected were peaked in June $(\mathrm{GCI}=77.8 \%)$ when the average temperature reached $22.7{ }^{\circ} \mathrm{C}$. At that time, sunshine duration was about 12 hours and precipitation was at the lowest level $(0.9 \mathrm{~mm})$ of the entire study period (Table 3). On the other hand, the lowest GCI value was in May, when the average temperature reached $12.4{ }^{\circ} \mathrm{C}$, sunshine duration was about 6 hours and precipitation was at the highest level of the study $(3.2 \mathrm{~mm})$.

Table 2 Mosquito larvae productivity at the cemeteries inspected from May to September 2019

\begin{tabular}{llllll}
\hline \multirow{2}{*}{ Cemetery } & \multicolumn{5}{l}{$\begin{array}{l}\text { General container index, \% } \\
\text { (Number of water supply wells inspected) }\end{array}$} \\
\cline { 2 - 6 } & May & June & July & August & September \\
\hline Bujwida (BU) & 0 & 91.67 & 91.67 & 75.00 & 33.33 \\
& $(6)$ & $(12)$ & $(12)$ & $(12)$ & $(12)$ \\
Grabiszynski (GR) & 42.5 & 84.67 & 84.25 & 82.7 & 55.86 \\
& $(80)$ & $(137)$ & $(127)$ & $(133)$ & $(145)$ \\
Jerzmanowo (JE) & 0 & 16.66 & 11.11 & 22.22 & 16.66 \\
& $(9)$ & $(18)$ & $(18)$ & $(18)$ & $(18)$ \\
\hline
\end{tabular}

\section{Discussion}

The results of our study suggest that the cemeteries of Wrocław may act as variable and important breeding areas for native mosquito species within their densely urbanized neighborhoods (Vezzani et al. 2001). The most likely explanation for the high abundance of mosquitoes and frequency of infested water supply wells during the season, is in part, due to permanent presence of water and frequent human activity in cemeteries. Our study also confirms that monitoring the breeding of mosquitoes in artificial containers is a suitable approach as these containers provide numerous habitats for larvae of native mosquito species and are easily accessible for investigators (Vezzani 2007; Kampen et al. 2016). According to Vezzani (2007), compared to pools, ponds, swamps, and rice fields, different types of artificial containers are: (a) significantly smaller and, therefore, support fewer species with smaller population sizes (b) habitats with almost no internal productivity, based mainly on the decomposition of leaf litter and other detritus, and (c) a home to larval mosquito populations, which are regulated by food limitation or competitive interactions rather than predation (Vezzani 2007). Nevertheless, cemeteries are still an underestimated breeding site for mosquitoes. Annual mosquito productivity in a cemetery is estimated to be 12 million larvae and, on any given day of the year, it can be between 2.5 and 60 million larvae (Vezzani 2007).

All the three inspected cemeteries in Wroclaw differed in the area and the number of suitable breeding sites, as well as the number of mosquitoes in their immature stages. However, in the present study GR cemetery showed the highest number of water supply wells infestation and the highest GCI values. These results are similar to previous data collected in 2013 within water supply wells in another large cemetery in Wrocław - Osobowicki cemetery, when the development of mosquito larvae was observed from May to September and the GCI was $48.28 \%$ (Rydzanicz, unpublished data). Our observations have also shown that a cemetery with a small area and a small number of wells (BU cemetery) can provide favourable conditions for mosquito development and, thus, leads to adult females causing nuisance. A survey carried out in rural and urban cemeteries in Buenos Aires showed, 
Table 3 Average value of selected climatic parameters in relation to container indices at the cemeteries of Wrocław from May to September 2019

\begin{tabular}{llllll}
\hline Parameter & May & June & July & August & September \\
\hline Number of supply water wells inspected & 95 & 167 & 157 & 163 & 175 \\
GCI $(\%)$ & 35.8 & 77.8 & 74.5 & 74.8 & 50.3 \\
Air temperature $\left[{ }^{\circ} \mathrm{C}\right]$ & 12.4 & 22.7 & 20.2 & 21.2 & 15.2 \\
Precipitation $[\mathrm{mm}]$ & 3.2 & 0.9 & 1.6 & 1.4 & 1.9 \\
Sunshine duration per day $[\mathrm{h}]$ & 6.6 & 12.1 & 8.3 & 8.2 & 6.6 \\
\hline
\end{tabular}

in addition, that the mean annual temperature, photoperiod variability, shade and time of the season were key drivers of distribution of immature mosquitoes grouped in the complex Culex pipiens L. collected from flower vases and other artificial containers (Vezzani and Albicócco 2009, Cardo et al. 2020). Also in our study the seasonal (summer) peak of immature mosquitoes dynamics was observed mainly in June when the average temperature reached $22.7^{\circ} \mathrm{C}$ and sunshine duration was about 12 hours. Given these observations, it is suggested that our future study in cemetery areas should be improved by detailed analysis on the effects of shade and vegetation on the container index and immature stages productivity of the mosquitoes.

The presence and development of Aedes invasive mosquito species has not been confirmed by our study. Their occurrence has been noted in neighboring countries such as the Czech Republic, Germany and Slovakia (Šebesta et al. 2012, Bocková et al. 2013, Kuhlisch et al. 2018) and on several occasions the public have been concerned about the potential presence of Ae. albopictus in Poland. Between 2016 and 2019, several adult mosquito females were sent to our laboratory by private persons as suspected "invasive Aedes species". However, in every case they were identified as Culiseta annulata Schrank (80\%), Ae. vexans Meigen (15\%) and $C x$ pipiens s.l. in $5 \%$ (Rydzanicz, unpublished data). Females $C s$. annulata are known to be a biting nuisance and frequently enters people's dwellings for hibernation.

In our study, all mosquito larvae collected from 492 positive water supply wells in Wrocław's cemeteries were identified as Culex pipiens s.1., Cx torrentium and An. maculipennis s.l. but it should be emphasized that adult mosquitoes belonging to the Culex pipiens complex and Anopheles maculipennis complex cannot be reliably distinguished based on morphological characteristics only (Becker et al. 2010, Becker et al. 2012). Although, there are only 3 of the 48 species included in the Polish mosquito fauna, they are important from an epidemiological and veterinary point of view (Kubica-Biernat 1999; Rydzanicz et al. 2017). In the Holarctic Culex pipiens complex is known to comprise of $C x$ pipiens pipiens Linneaus, $C x$ pipiens biotype molestus Forskal, $C x$ quinquefasciatus Say, $C x$ pallens Coquillett, $C x$ restuans Theobald and $C x$ torrentium Martini (considered as a separate species because of the genetical distance to $C x$ pipiens) (Becker et al. 2012). Mosquito females of Culex pipiens complex are recognized as the main vector of West Nile virus
(WNV) in Europe (Lebl et al. 2015). They not only cause the enzootic amplification of WNV among avian hosts, they also act as bridge vectors to mammalian hosts (Molaei et al. 2006). They have also been shown to transmit the Sindbis virus (SINV), Usutu virus (USUV) and Tahyna virus (TAHV) (Hubálek 2008). The main vertebrate hosts for TAHV are small mammals but humans can also be infected; the virus then causes an influenza-like illness (Hubálek 2008).

Furthermore, the members of Culex pipiens complex are important vectors in the transmission of parasitic nematodes (e.g. Dirofilaria repens) and protozoans which cause dirofilariasis and avian malaria (Lebl et al. 2015). In turn, $C x$ torrentium - was experimentally established as most susceptible to Sindbis Virus (SINV), an ethiological agent of Ockelbo disease (Lundström 1994).

The sibling species of Anopheles maculipennis complex have been shown to be infected with viruses (Batai, Sindbis, Ťahyňa, West Nile) and parasites (D. immitis, D. repens, Setaria labiatopapillosa and Plasmodium vivax) (Jöst et al. 2010, 2011; Kronefeld et al. 2012, Czajka et al. 2014, Rydzanicz et al. 2017).

Although Culex sp. larvae were the most abundant in the water supply wells in our study, it should be emphasized that these kinds of breeding sites are also reliable indicators of the presence of invasive Aedes species such Ae. albopictus and Ae. japonicus. Recent surveys carried out in the Netherlands and Germany, have shown that artificial containers in cemeteries and allotments can be suitable places for the development of many mosquito larvae including Culex sp., Ae. albopictus and Ae. japonicus (Ibáñez-Justicia et al. 2018; Kuhlisch et al. 2018). Given the vector potential of both native and invasive Aedes mosquito species as well as awareness of the introduction of invasive species in combination with climatic and environmental changes, may lead to an increase likelihood of the establishment, adaptation and developmental rate of vectors to new environments. With this in mind, the search for suitable mosquito breeding sites in Polish cemeteries should be continued and expanded.

\section{Conclusions}

In the city of Wrocław, cemeteries are suitable areas for the breeding of native mosquito species. The development rate of mosquito larvae in the cemeteries is constant, which results in 
females causing a nuisance to both guests and local residents. The developmental rate of mosquito larvae of native species within generally accessible water supply wells is dynamic and adapted to the current environmental conditions. For this reason and due to the likelihood of the establishment and adaptation of new invasive vector aedine species in Poland, constant analysis of the quantitative and qualitative composition of mosquito larvae in cemeteries should be continued.

Acknowledgements We appreciate the active cooperation with the Wrocław's Municipal Government (Department of Environment and Agriculture) which provided financial support of this study.

\section{Declarations}

Conflict of interest The authors declare that they have no conflict of interest.

Open Access This article is licensed under a Creative Commons Attribution 4.0 International License, which permits use, sharing, adaptation, distribution and reproduction in any medium or format, as long as you give appropriate credit to the original author(s) and the source, provide a link to the Creative Commons licence, and indicate if changes were made. The images or other third party material in this article are included in the article's Creative Commons licence, unless indicated otherwise in a credit line to the material. If material is not included in the article's Creative Commons licence and your intended use is not permitted by statutory regulation or exceeds the permitted use, you will need to obtain permission directly from the copyright holder. To view a copy of this licence, visit http://creativecommons.org/licenses/by/4.0/.

\section{References}

Becker N, Petrić D, Zgomba M, Boase C, Dahl C, Lane J, Kaiser A (2010) Mosquitoes and their control. 2nd ed. Kluwer Academic/ Plenum Publishers, New York. ISBN 978-3-540-92874-4

Becker N, Huber K, Pluskota B, Kaiser A (2011) Ochlerotatus japonicus japonicus - a newly established neozoan in Germany and a revised list of the German mosquito fauna. Eur Mosq Bull 29:88-102

Becker N, Jöst A, Weitzel T (2012) The Culex pipiens complex in Europe. J Am Mosq Control Assoc 28:53-67

Bocková E, KočišováA, Letková V (2013) First record of Aedes albopictus in Slovakia. Acta Parasitol 58:603-606. https://doi.org/ 10.2478/s11686-013-0158-2

Burak M, Okólska H (2007) Cmentarze dawnego Wrocławia. Wydawnictwo Muzeum Architektury, Wrocław. ISBN 978-8389262-38-7

Cardo MV, Rubio A, Junges MT, Vezzani D, Carbajo AE (2020) A rural-urban latitudinal study of the distributions of Culex quinquefasciatus and Culex pipiens bioforms in their southernmost sympatric fringe. Med Vet Entomol 34:34-43. https://doi.org/10. $1111 /$ mve. 12400

Cichocki Z (2006) Środowisko Wrocławia. Informator 2006. Minolta WK, Wrocław

Czajka C, Becker N, Jöst H, Poppert S, Schmidt-Chanasit J, Krüger A, Tannich E (2014) Stable transmission of Dirofilaria repens Nematodes, Northern Germany. Emerg Infect Dis 20:329-331. https://doi.org/10.3201/eid2002.131003

Dallimore T, Hunter T, Medlock JM, Vaux ACG, Harbach RE, Strode C (2017) Discovery of a single male Aedes aegypti (L.) in Merseyside,
England. Parasit Vectors 10:309. https://doi.org/10.1186/s13071017-2251-0

European Centre for Disease Prevention and Control-ECDC (2012) Guidelines for the Surveillance of invasive mosquitoes in Europe. Euro Surveill 17:36. https://doi.org/10.2900/61134

Gizowska A, Szopińska E (2013) Osiedle Jerzmanowo. In: Bińkowska I, Szopińska E (eds) Leksykon zieleni Wrocławia. Via Nova. Wrocław. p 348

Hubálek Z (2008) Mosquito-borne viruses in Europe. Parasitol Res 103: S29-S43. https://doi.org/10.1007/s00436-008-1064-7

Ibáñez-Justicia A, Teekema S, den Hartog W, Jacobs F, Dik M, Stroo A (2018) The effectiveness of Asian bush mosquito (Aedes japonicus japonicus) control actions in colonised peri-urban areas in the Netherlands. J Med Entomol 55:673-680. https://doi.org/10.1093/ jme/tjy002

Instytut Meteorologii i Gospodarki Wodnej - Państwowy Instytut Badawczy/ The Institute of Meteorology and Water Management National Research Institute (2019) Rocznik Meteorologiczny, Warszawa. https://danepubliczne.imgw.pl

Jöst H, Bialonski A, Storch V, Günther S, Becker N, Schmidt-Chanasit J (2010) Isolation and phylogenetic analysis of Sindbis viruses from mosquitoes in Germany. J Clin Microbiol 48:1900-1903

Jöst H, Bialonski A, Schmetz C, Günther S, Becker N, Schmidt-Chanasit J (2011) Isolation and phylogenetic analysis of Batai virus, Germany. Am J Trop Med Hyg 84:241-243

Kalan K, Šušnjar J, Ivović V, Buzan E (2017) First record of Aedes koreicus (Diptera, Culicidae) in Slovenia. Parasitol Res 116:23552358. https://doi.org/10.1007/s00436-017-5532-9

Kampen H, Kuhlisch C, Fröhlich A, Scheuch DE, Walther D (2016) Occurrence and spread of the invasive Asian bush mosquito Aedes japonicus japonicus (Diptera: Culicidae) in West and North Germany since detection in 2012 and 2013, respectively. PLoS One 11(12):e0167948. https://doi.org/10.1371/journal.pone. 0167948

Klobučar A, Lipovac I, Žagar N, Mitrović-Hamzić S, Tešić V, VilibićČavlek T, Merdić E (2018) First record and spreading of the invasive mosquito Aedes japonicus japonicus (Theobald, 1901) in Croatia. Med Vet Entomol 33:171-176. https://doi.org/10.1111/ mve. 12337

Koban MB, Kampen H, Scheuch DE, Frueh 1, Kuhlisch C, Janssen N, Steidle JLM, Schaub GA, Werner D (2019) The Asian bush mosquito Aedes japonicus japonicus (Diptera: Culicidae) in Europe, 17 years after its first detection, with a focus on monitoring methods. Parasit Vectors 12:109. https://doi.org/10.1186/s13071-019-3349-3

Kondracki J (2000) Geografia regionalna Polski (Regional geography of Poland). PWN, Warszawa

Krebs T, Bindler P, L'Ambert G, Toty C, Perrin Y, Jourdain F (2014) First establishment of Aedes japonicus japonicus (Theobald, 1901) (Diptera: Culicidae) in France in 2013 and its impact on public health. J Vector Ecol 39:437-440. https://doi.org/10.1111/jvec. 12119

Kronefeld M, Dittmann M, Zielke D, Werner D, Kampen H (2012) Molecular confirmation of the occurrence in Germany of Anopheles daciae (Diptera, Culicidae). Parasit Vectors 5:250. https://doi.org/10.1186/1756-3305-5-250

Krüger A, Börstler J, Badusche M, Lühken R, Garms R, Tannich E (2014) Mosquitoes (Diptera: Culicidae) of metropolitan Hamburg, Germany. Parasitol Res 113:2907-2914

Kubica-Biernat B (1999) Distribution of mosquitoes (Diptera: Culicidae) in Poland. Eur Mosq Bull 5:1-17

Kuhlisch C, Kampen H. Walther D (2018) The Asian tiger mosquito Aedes albopictus (Diptera: Culicidae) in Central Germany: Surveillance in its northernmost distribution area. Acta Trop 188: 78-85. https://doi.org/10.1016/j.actatropica.2018.08.019

Lebl K, Zittra C, Silbermayr K, Obwaller A, Berer D, Brugger K, Walter M, Pinior B, Fuehrer HP, Rubel F (2015) Mosquitoes (Diptera: 
Culicidae) and their relevance as disease vectors in the city of Vienna, Austria. Parasitol Res 114:707-713. DOI https://doi.org/ 10.1007/s00436-014-4237-6

Lundström JO (1994) Vector competence of Western European mosquitoes for arboviruses: are view of field and experimental studies. Bull Soc Vector Ecol 19:23-36

Medlock JM, Hansford KM, Schaffner F, Versteirt V, Hendrickx G, Zeller H, Van Bortel W (2012) A review of the invasive mosquitoes in Europe: ecology, public health risks, and control options. Vector Borne Zoonotic Dis 12(6):435-447. https://doi.org/10.1089/vbz. 2011.0814

Medlock J, Hansford KM, Versteirt V, Cull B, Kampen H, Fontenille D, Hendrickx G, Zeller H, Van Bortel W, Schaffner F (2015) An entomological review of invasive mosquitoes in Europe. Bull Entomol Res 105:637-663. https://doi.org/10.1017/S0007485315000103

Molaei G, Andreadis TG, Armstrong PM, Anderson JF, Vossbrinck CR (2006) Host feeding patterns of Culex mosquitoes and West Nile virus transmission, northeastern United States. Emerg Infect Dis 12: 468-474. https://doi.org/10.3201/eid1203.051004

Montarsi F, Martini S, Dal Pont M, Delai N, Ferro Milone NF, Mazzucato M, Soppelsa F, Cazzola L, Cazzin S, Ravagnan S, Ciocchetta S, Russo F, Capelli G (2013) Distribution and habitat characterization of the recently introduced invasive mosquito Aedes koreicus [Hulecoeteomyia koreica], a new potential vector and pest in north-eastern Italy. Parasit Vectors 6:292. https://doi.org/10.1186/ 1756-3305-6-292

Montarsi F, Drago A, Martini S, Calzolari M, De Filippo F, Bianchi A, Mazzucato M, Ciocchetta S, Arnoldi D, Baldacchino F, Rizzoli A, Capelli G (2015) Current distribution of the invasive mosquito species, Aedes koreicus [Hulecoeteomyia koreica] in northern Italy. Parasit Vectors 8:614. https://doi.org/10.1186/s13071-015-1208-4

Petrić D, Bellini R, Scholte EJ, Rakotoarivony LM, Schaffner F (2014) Monitoring population and environmental parameters of invasive mosquito species in Europe. Parasit Vectors 7:187. https://doi.org/ 10.1186/1756-3305-7-187

Pfitzner WP, Lehner A, Hoffmann D, Czajka Ch, Becker N (2018) First record and morphological characterization of an established population of Aedes (Hulecoeteomyia) koreicus (Diptera: Culicidae) in Germany. Parasit Vectors 11:662. https://doi.org/10.1186/s13071018-3199-4

Pluskota B, Storch V, Braunbeck T, Beck M, Becker N (2008) First record of Stegomyia albopicta (Skuse) (Diptera: Culicidae) in Germany. Eur Mosq Bull 26:1-5

Przewrocka A, Ziemiańska M (2013a) Cmentarz komunalny na Grabiszynie. In: Bińkowska I, Szopińska E (eds) Leksykon zieleni Wrocławia. Via Nova. Wrocław. pp 399

Przewrocka A, Ziemiańska M (2013b) Cmentarz św. Wawrzyńca. In: Bińkowska I, Szopińska E (ed.) Leksykon zieleni Wrocławia. Via Nova. Wrocław. pp 639-640

Rydzanicz K, Czułowska A, Manz Ch, Jawień P (2017) First record of Anopheles daciae (Linton, Nicolescu \& Harbach, 2004) in Poland. J Vector Ecol 42(1):196-199. https://doi.org/10.1111/jvec.12257
Schaffner F, Kaufmann C, Hegglin D, Mathis A (2009) The invasive mosquito Aedes japonicus in Central Europe. Med Vet Entomol 23:448-451. https://doi.org/10.1111/j.1365-2915.2009.00825.x

Schneider K (2011) Breeding of Ochlerotatus japonicus japonicus (Diptera: Culicidae) $80 \mathrm{~km}$ north of its known range in southern Germany. Eur Mosq Bull 29:129-132

Šebesta O, Rudolf I, Betášová L, Peško J, Hubálek Z (2012) An invasive mosquito species Aedes albopictus found in the Czech Republic, 2012. Euro Surveill 17(43):20301. https://doi.org/10.2807/ese.17. 43.20301-en

Seidel B, Nowotny N, Bakonyi T, Allerberger F, Schaffner F (2016) Spread of Aedes japonicus japonicus (Theobald, 1901) in Austria, 2011-2015, and first records of the subspecies for Hungary, 2012, and the principality of Liechtenstein, 2015. Parasit Vectors 9:356. https://doi.org/10.1186/s13071-016-1645-8

Vezzani D (2007) Artificial container-breeding mosquitoes and cemeteries: a perfect match. Trop Med Int Health 12(2):299-313. https:// doi.org/10.1111/j.1365-3156.2006.01781.x

Vezzani D, Albicócco AP (2009) The effect of shade on the container index and pupal productivity of the mosquitoes Aedes aegypti and Culex pipiens breeding in artificial containers. Med Vet Entomol 23: 78-84. https://doi.org/10.1111/j.1365-2915.2008.00783.x

Vezzani D, Velázquez SM, Soto S, Schweigmann NJ (2001) Environmental characteristics of the cemeteries of Buenos Aires city (Argentina) and infestation levels of Aedes aegypti (Diptera: Culicidae). Mem Inst Oswaldo Cruz 96:467-471. https://doi.org/ 10.1590/S0074-02762001000400005

Vezzani D, Rubio A, Velázquez SM, Schweigmann N, Wiegand T (2005) Detailed assessment of microhabitat suitability for Aedes aegypti (Diptera: Culicidae) in Buenos Aires, Argentina. Acta Trop 95:123-131. https://doi.org/10.1016/j.actatropica.2005.03.010

Werner D, Kampen H (2013) The further spread of Aedes japonicus japonicus (Diptera, Culicidae) towards northern Germany. Parasitol Res 112:3665-3668. https://doi.org/10.1007/s00436-0133564-3

Werner D, Kronefeld M, Schaffner F, Kampen H (2012) Two invasive mosquito species, Aedes albopictus and Aedes japonicus japonicus, trapped in Southwest Germany, July to August 2011. Euro Surveill 7(4):20067. https://doi.org/10.2807/ese.17.04.20067-en

Zielke DE, Ibáñez-Justicia A, Kalan K, Merdić E, Kampen H, Werner D (2015) Recently discovered Aedes japonicus japonicus (Diptera: Culicidae) populations in The Netherlands and northern Germany resulted from a new introduction event and from a split from an existing population. Parasit Vectors 8:40. https://doi.org/10.1186/ s13071-015-0648-1

Zielke DE, Walther D, Kampen H (2016) Newly discovered population of Aedes japonicus japonicus (Diptera: Culicidae) in Upper Bavaria, Germany, and Salzburg, Austria, is closely related to the Austrian/ Slovenian bush mosquito population. Parasit Vectors 9:163. https:// doi.org/10.1186/s13071-016-1447-z

Publisher's note Springer Nature remains neutral with regard to jurisdictional claims in published maps and institutional affiliations. 